\title{
Advertising Design as Cultural Strategy
}

Designers, otherwise active in the field of visual arts, were also active in commercial communication within the context of state-planned economy in former socialist Yugoslavia, and in Croatia, industrially the most developed federal state. Since there was no significant market competition the artists engaged in "advertising graphics" had considerable freedom of expression, exploration and application of innovative communication concepts. The 50's was a time of consensual economy, when the state, through its five-year's plan based on the soviet model, shaped the economy following the idea of industrial modernisation, workers participation ("self-governance") and material welfare. Due to its inadequate financial efficacy, the Communist party decided to introduce "economic reform" in 1963. It had elements of free market competition built into the state-planned economy. In both of these socio-economic models, advertising was considered as a key cultural strategy.

keywords design, advertising, social context, state-planned economy

\section{Introduction}

Paper purports to examine graphic design for advertising within the context of socialist selfgovernment in order to broaden the knowledge on cultural history of this historical model. A number of graphic artworks designed by artists for publishing in mass media advertising campaigns could be identified throughout the public collections of visual arts and private archives in contemporary Croatia. Authors otherwise active in the field of visual arts, were also active in commercial communication within the context of stateplanned economy in former socialist Yugoslavia. Since there was no significant market competition, and therefore no need for strong distinction through symbolic values, all large production companies were focused on their primarily task: industrial production of goods. Consequently, the artists engaged in "advertising graphics" had considerable freedom of expression, exploration and application of innovative communication concepts. Some of them even applied their experimental and research work to commercial graphics.

\section{A Historical Grammar of Advertising}

Visual semantic mechanisms of advertising in a social and political context could be analysed through analogy to the "historical grammar of art", bearing in mind typology of communication of a work of art and the difference in their functional, ornamental and imaginative roles. (Riegl 2000:111-112). Analogy to Riegl's definition could be found in four formats of advertising as discussed by Leiss, Kline, Jhally in connection with four cultural frames for consumer goods: product-information, equal to idolatry, product-image, equal 
to iconology and personalized format, equal to narcissism, and lifestyle format, equal to totemism. (Leiss, Kline, Jhally 1997:236-262/329). This model is crucial to understanding of cultural function of advertising, which reflects, to a certain degree, the development of the service industry, i.e., the economic model of "postfordist" capitalism (Julier 2000: 20-23).

Graphic design for advertising could thus be understood as a cultural strategy of a large scale economy, i.e. of liberal capitalism. Individual creativity is thus put to practice and approved by the main actors of capital-labour relationship. During the $2 \mathrm{O}^{\text {th }}$ century, graphic advertising contributed to the establishment of mass culture as a social frame for materialistic and symbolic consuming. (Schwartz 1996: 164, 192)). But the topic of advertising in programmed (state-planned) economy was not subject to broader research until recently (Patterson 2011, Ibroscheva 2013)) and it appears as a interesting area for the future researchers, as a point to semantic and cultural aspects of advertising design within the context different to free market one.

\section{Visual Mechanisms of Meaning}

A move from the explicit expression of value of merchandise to implicit indication of value of a lifestyle is evident in history of advertising, because «a decline in textual material with a correlative increase in visualised images of well-being" in graphic advertising is evident (Jhally 1990:22), as it was demonstrated already in the 50s. Decrease of textual explications and increase of images enhance the persuasiveness of an advert and its antiinterpretative function, adding to its assertiveness (Packard 1957:71-82).

In the course of this visual mechanism and in the grammar of advertising, a new type of work, "advertising work", appears as an important instrumental tool, complementing Freud's idea of "dream-work" as a basis for dream. (Williamson 1978: 19). This theory reposes on the idea of identity situations as basis for advertising, i.e. on the idea that the value of an advertisement is created through the creator-advertiser-medium-consumer relation, which will eventually bring to the added value (Du Gay, Evans, Redman 2000:277383). The point of value of the process is identity.

\section{Advertising as Cultural Strategy}

Individual and collective identity are often in semiotic connection through the symbolic affiliation of material ownership in advertising. But, does advertising influence in the same way the individual and social identity, through "directing the flow of symbols", in a liberal economy as it did in the state controlled economy? (Leiss, Kline, Jhally 1997:124-130) The question is interesting, as one can clearly identify an intense advertising activity during the 50's and the 6o's in the historical context of the state controlled economy (Hanson 1974: 123-128). At the time, the strong ideological division of the world made it difficult to realise that industrial modernization, a key project and process and the palpable witness of the achievement of a society, existed as such in both of those worlds (Patterson 2011:113-116).

This fact is still relevant to the study of the culture of socialism, which disappeared in 1990 and can be studied today as a historical fact. The 50's in former Yugoslavia was a time of consensual economy, when the state, through its five-year's plan based on the soviet model, shaped the economy following the idea of industrial modernisation, workers participation ("self-governance") and material welfare.

However, in the early 6o's this model was already disputed in the highest-level political forums. Due to its inadequate financial efficacy, the Communist party decided to introduce 
"economic reform" in 1963. It had elements of free market competition built into the stateplanned economy. Design theory and practice at the time was a clear attempt of intellectuals, artists, architects and art historians, to elaborate in public the need for creative contribution to ideological change (Vukic 2007:235).

The reform of the economy was one of the main conceptual grounds (together with the later new Federal constitution of 1975) for the hybrid model of Yugoslav socialism, which was half way between the hard-line Soviet model and the ideologically opposed soft western approach, yet closer to a model of a liberal economy. For these reasons, at a cultural level, the 50's and 6o's are not entirely the same. This particularly transpires through various levels of cultural production: new phenomena in film, literature and visual arts, the new media culture and in new forms of mass happenings, such as festivals of popular music, being the origin of a new cultural industry. This change is evident in the domain of commercial communication (Vukic 2007:237).

Television broadcast in Yugoslavia started in 1956, and in archives first examples of television ads could be traced not before mid sixties. Newspaper ads had become a standard means of commercial campaigning by early sixties. Therefore posters in public space and commercial catalogues for trade fairs were the only existing practice of advertising within the context of self-management social system, introduced in 1952. Until the introduction of economic reform printed posters were the unique medium of transferring the idea of industrial modernization to mass public.

\section{Case Studies}

Aleksandar Srnec was a very active author throughout the 1950'. He was a founding member of EXAT 51 experimental art group and a visual artist who adopted various models of creative research, from abstract painting to sculpture and lumino-kinetic objects. (Vukic 2007a: 363-368). He was also active in the field of graphic design for commercial communication, creating advertising and posters and magazine and book covers. Numerous examples show that Srnec continously applied to his advertising work the forms and solutions reached in his artistic research such as abstract compositions or photo collages (Fig 1.). In Yugoslavia, in the 50's, there were only two state-owned advertising agencies employing designers which accorded their designers a substantial margin of artistic liberty.

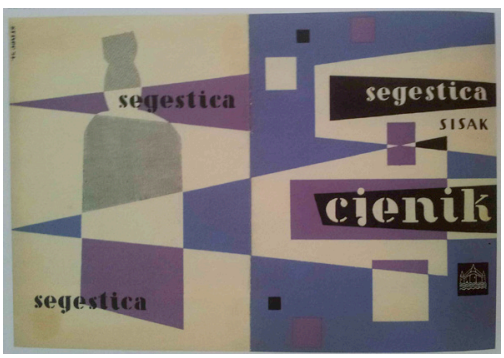

Figure 1. Design for advertising catalogue or Segestica alcoholic beverages producer, Design: Aleksandar Srnec 1954, offset print, $169 \times 244$

Upon the introduction of economic reform in 1963, the same system of agency-controlled advertising persisted. Although industrial production was still state controlled, production companies were allowed to manage its profits more independently. This gave rise to investments in advertising and promotion. During the 60 's, first in-house marketing and 
theme 2

memory

Figure 2.

Poster for food processing company, Design: Zvonimir Faist, litography, $990 \times 695$ strand 2

design culture

advertising departments were founded within the companies, which gradually take over the creative part while state agencies still controled the media buying. Individual authors benefited from an even larger creative margin as they could work as free-lance designers affiliated to various professional associations.

An exemple that illustrates the changes of the 6o's is Zvonimir Faist's poster for "Zvijezda" (Star) oil. (Kolveshi 2003:108). The visual describes the ambience in the shop, a selfservice shop which precisely in this period started replacing the usual behind-the-counter shops (Fig. 2.) The visual displays a woman with obvious feminine attributes buying oil. Headline of the poster says: "Dobra izbira" (Good Choice). However, there is only one brand of oil on the shelves, the one that is being advertised: every choice is a good choice provided that you choose this.

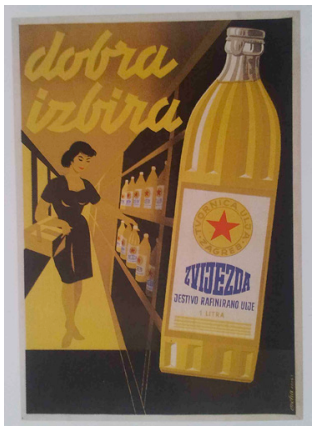

In spite of newly introduced economic reform there was still only one option offered. Symbolic production here complements the promotion of ideology. So, in spite of ideological differences, the platform for the desire to acquire and consume material goods is the same on both sides of ideological divide: it is essentially based on displaying a fantasy lifestyle.

Upon the introduction of economic reform commercial communication grew stronger in terms of the volume of media presence. The need to display the results of industrial modernisation migrated from the domain of declarative political parades to the domain of advertising similar to the semiotic mechanisms of liberal economy.

Examples similar to ones described in this paper are within some collections and contemporary publications from other socialist countries at the time. Slovenia and Croatia were the foremost industrially developed republics of Yugoslavia, and commercial communication. But since advertising found no justification within the ideologically correct models of public activity, the new nick name was invented to designate the practice - "economic propaganda". It was a sort of additional tool to politic propaganda.

In Slovenia during the fifties posters were under heavy influence of Swiss typographic solutions connected to reproduced photo, with discrete color interventions. But from sixties on, more complex form of posters was seen, as corporate identity design, even redesign of existing identities, since companies were allowed to use more of financial "surplus", as the contemporary expression designates profit than. In Croatia, ideology signs were removed from corporate identity of some key companies, but the practice of "branding" them with the names of war heroes remained. Such a shift due to economic 
reform was specific to Yugoslavia and it is not present in hardcore countries within the Warsaw pact, from which Yugoslavia had dropped out after 1948.

But during the Thaw years in Poland, similar shifts in commercial communication are documented (Crowley 2008:130-133), since the context was defined somewhat similar to Yugoslav efforts to re-create economy which did not perform well in financial aspects.

Therefore the usage of fashion models photography, the manipulation with the sex appeal and more vernacular typography solutions appeared in Poland, as it was the case in Yugoslavia.

\section{Conclusion}

The semantics of market communication of 50 and 6 os clearly reveal symptoms of the existing social and economic system, which was formed on the idea of equality but which did not last long in the execution of this idea. It was a system that, in the early 6o's, tried to entice a more realistic rate of economic development by introducing more liberal economic policies.

During the years of state-planned economy, visual identities and various means of market communication primarily inform on new products on the market, considered as a tangible success of social and political conception. Nevertheless, advertising forms used provide this seemingly superficial intention with a very high level of material and symbolic visibility. Billboards, advertisements and other means of public communication show a good amount of original expression as an important (and yet un-researched) part of the visual culture of the immediate past. These apparently contradictory social drives, the ideological importanceof a state-planned economy on one hand, and the idea of consumerist behaviour on the other, had coexisted within advertising as a cultural strategy of the time.

Future research of advertising design in programmed economy should concentrate on issues of clients as subjects of advertising activity, as to point out social mission of such an activity. Semantic agenda should be pointed out too, within structural analysis of the content and in comparision with examples from similar (programmed economy) and different (free market economy) contexts, as to discover the field of the signifier and trace the effects of advertising activity within that field. Finally, a more comprehensive research in variety of media should be carried out, with the focus on period from 1963. and on, when the economic reform within self-management socialism carried out more activity in television advertising and newspaper ads. Finally, comprehension of formal elements and semantic logic of advertising in socialism could provide with better understanding of social role of actual fashion of "vintage" graphics within the context of post-socialist neoliberal national countries.

\section{References}

Crowley D., Thaw Modern: Design in Eastern Europe after 1956, in: Crowley, pavitt (eds.), Cold War Modern, design 1945-1970., V\&A Publishing, London 2008, p.128-153

Du Gay, P., Evans, J., Redman, P.(eds.), (2000) Identity: A Reader, Sage Publications, London Hanson, P., (1974), Advertising and Socialism, International Arts and Sciences Press, New York Ibroscheva, E., Advertising, Sex and Post-Socialism: Women, Media and Femininity in

Balkans, Lexington Books, London 2013, p.47-75

Jhally, S., (1990) The Codes of Advertising, Fetishism and Political Economy in the 
Consumer Society, Routledge, London

Julier, G.,(2000) The Culture of Design, Sage , London

Leiss, W., Kline, S., Jhally, S.,(1997) Social Communication in Advertising, Persons, Products and Images of Well Being, Routledge, London

Kolveshi, Z. (2003), Zvonimir Faist . diktati vremena: plakati od ranih 1930-ih do 1960in (Dictates of Time - posters from early 1930' to early 1960'), Muzej grada Zagreba (Museum of the City of Zagreb)

Mauss, M., A Category of Human Mind: the Notion of 'Person'; the Notion of 'Self', in: Du Gay, P., Evans, J., Redman, P. (eds.),(2000) Identity: A Reader, Sage Publications, London Packard, V. (1957), The Hidden Persuaders, Cardinal Editions, New York

Patterson, P.H. (2011) , Bought and Sold, Living and Losing the Good Life in Socialist Yugoslavia, Cornell University Press, Ithaca and London

Riegl, A., Introduction to A Historical Grammar of the Visual Arts (1897-1899), u: Frank I. (ed.),(2000) The Theory of Decorative Art, Yale university Press, New Haven and London Schwartz, F.J.,(1996), The Werkbund, Design Theory and Mass Culture before the First World War, Yale University Press

Vukic, F. (2007), Socialist Lifestyle and Mass Consumption, in: Blau, E. and Rupnik, I. (eds), Project Zagreb, Transition as Condition, Strategy, Practice, GSD Harvard University, Actar Publications

-Vukic, F., (2007a) Present Absence, Aleksandar Srnec's Personality and Artistic Oeuvre in the Context of the Industrial /socialist/ Modernisation of Society), in: Sudac M. ur., Present Absence, edicija Sudac, Zagreb 2007., reproduction of poster design p.384 Williamson, J.,(1978) Decoding Advertisements, Ideology and Meaning in Advertising, Marion Boyars, London New York 